
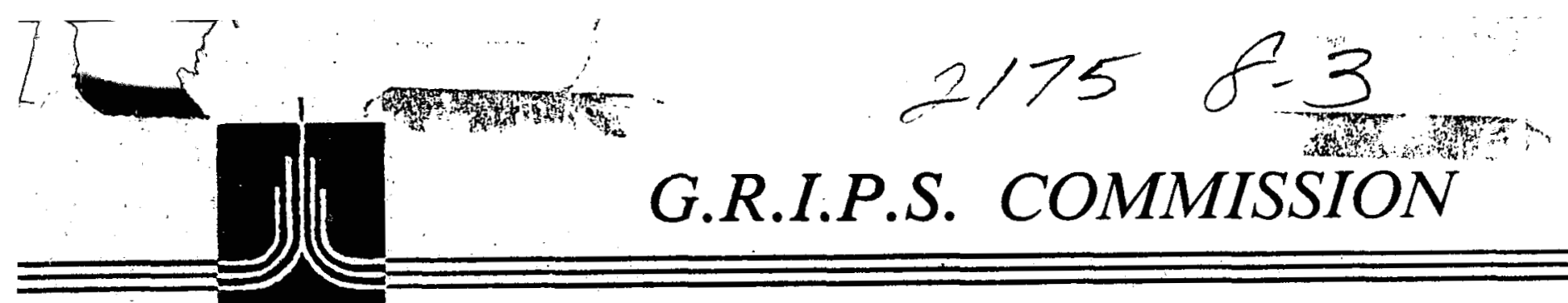

2628 MENDOCINO AVENUE, SANTA ROSA, CALIFORNIA 95401 (707) 527-2025

$$
\begin{array}{r}
F G 03-78 \text { ET27152 } \\
\text { DOE|ET/27152.T2 }
\end{array}
$$

PHASE II DRAFT FINAL REPORT

February 1, 1979 - August 31, 1979

$$
\text { SUBMITTED TO: }
$$

THE CALIFORNIA STATE ENERGY COMMISSION

Under Contract $\$ 500-137(7 / 8)$

$$
\text { August } 20,1979
$$

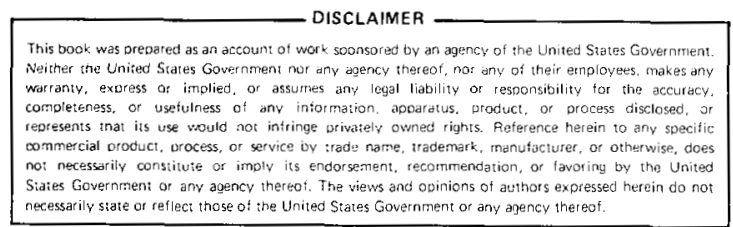

Geothermal Research Information and Planning Services/A California Joint Powers Agency

Lake County

Mendocino County
Napa County

Sonoma County 


\section{DISCLAIMER}

This report was prepared as an account of work sponsored by an agency of the United States Government. Neither the United States Government nor any agency Thereof, nor any of their employees, makes any warranty, express or implied, or assumes any legal liability or responsibility for the accuracy, completeness, or usefulness of any information, apparatus, product, or process disclosed, or represents that its use would not infringe privately owned rights. Reference herein to any specific commercial product, process, or service by trade name, trademark, manufacturer, or otherwise does not necessarily constitute or imply its endorsement, recommendation, or favoring by the United States Government or any agency thereof. The views and opinions of authors expressed herein do not necessarily state or reflect those of the United States Government or any agency thereof. 


\section{DISCLAIMER}

Portions of this document may be illegible in electronic image products. Images are produced from the best available original document. 
The G.R.I.P.S. Commission (Geothermal Research Information and Planning Services) is a Joint Powers Agency established by Lake, Mendocino, Napa, and Sonoma counties. It was established solely to deal with geothermal development at the Geysers-Calistoga Known Geothermal Resource Area shared by the four participating counties. The primary function of G.R.I.P.S. is to assist agencies involved in the geothermal permitting process in expediting environmentally sound decision making. Membership tofthe Commission consists of a Supervisor from each of the four counties as voting members, and non-voting members representing the California Energy Commission and the U.S. tit Department of Energy.

G.R.I.P.S. Commission Members

Lake County

Mendocino County

Napa County

Sonoma County

California Energy Commission

U.S. Department of Energy
Supervisor Doris Wilcox Supervisor Ray Mostin, Alternate

Supervisor James Eddie, Vice-Chairman Supervisor Norm DeVall, Alternate

Supervisor Dowell Martz, Chairman Supervisor Harold Moskowite, Alternate Supervisor Nick Esposti Vacant Alternate Conmissioner Suzanne Reed Staff: Nancy Deller, David Hill

Regional Representative William Arntz Staff: John Crawford

G.R.I.P.S. Technical Advisory Committee Membership

Lake County

Mendocino County

Napa County

Sonoma County

G.R.I.P.S. Staff

Executive Director

Research Analyst

Secretary $10 / 78-4 / 79$

Secretary $4 / 79$

Comprehensive Air Monitoring

Program Project Coordinator
Beverly Westfall

Alternate Member Mary Jadiker

Jerry Heath

James Hickey

Tom Cordill

Robert F. Van Horn

Paula E. Blaydes

Janet Larkin

Sue Ellen Bolt

John T. Walser 
INTRODUCTION

I. ENVIRONMENTAL StUdies 1

II. INFORMATION EXCHANGE 9

III. FUNDING PROPOSALS 11

IV. ADMINISTRATION OF G.R.I.P.S. 11

$\begin{array}{ll}\text { V. SUMMARY } & 12\end{array}$

VI. ISSUES FOR FUTURE CONSIDERATION 13

APPENDICES

A. G.R.I.P.S. Commission - Design for Information Management System

B. G.R.I.P.S. Research Survey Form

C. Research Survey Follow-up Letter

D. Comprehensive Air Monitoring Program June 8, 1979. Meeting Notes

E. G.R.I.P.S. Administration - Proposal Summary

F. G.R.I.P.S. Commission 1979-80 County Geothermal Policy Development Proposal Sumnary

G. Covering Letter to James Walker, C.E.C. for Submission of C.A.M.P. Proposal March 13, 1979. 


\section{INTRODUCTION}

This report covers the second phase, February 1, 1979, to August 20, 1979, of a two-phase contract between the California Energy Commission and the G.R.I.P.S. Commission. The first phase extended from July 1, 1978, to January 31, 1979. With severa1 minor exceptions, the same general responsibilities were assigned in both phases.

During the first phase, the Commission recruited its first Executive Director and Secretary and established an office. It then undertook its contractual responsibilities with regard to the Geysers-Calistoga Known Geothermal Resource Area. These fell under four major headings:

1. Identification, monitoring, and coordination of environmental research;

2. Exchange of information on geothermal activities;

3. Development of proposals seeking funding for priority studies;

4. Administration of programs initiated by G.R.I.P.S.

The second phase activities have continued in these areas and are reported herein under the headings: I. Environmental Studies, II. Information Exchange, III. Funding Proposals, and IV. Administration of G.R.I.P.S. This report also contains a Summary and a discussion of Areas for Future Consideration.

\section{ENVIRONMENTAL STUDIES}

Included in the following report are eighteen environmental research activities in the Geysers-Calistoga KGRA monitored by G.R.I.P.S. during the second phase of this program. of the eighteen studies, twelve are currently funded, three have recently been completed and three are scheduled for funding during the coming year. Site-specific research projects being conducted as part of development planning or permit proposals for exploratory wells, full-field development well sites or power plant sites are not included in this listing.

Much of the information contained herein has been previously described in the Bi-Monthily Activities Reports. Current updates have been added where applicabie. 
A. G.R.I.P.S. COMMISSION ACTIVITIES

1. Peregrine Falcon Study: In the Phase I of the Falcon Study, Dr. Monte Kirven conducted visual field observations of the Peregrine Falcon's nesting and foraging sites through the 1978 breeding season. Phase II of the study was a radio telemetry monitoring program which attempted to provide more specific data concerning the Falcon's critical habitat.

Part of the funds originally allocated to G.R.I.P.S. from D.O.E. for direction of this phase were transferred to the Bureau of Land Management the last week of February.

The Bureau of Land Management then signed a $\$ 29,879$. contract on March 28, 1979, with Dr. James H. Enderson of Colorado Springs, Colorado, using $\$ 20,250$ of G.R.I.P.S. funds and $\$ 9,629$ of BLM funds. Dr. Enderson is a wildlife biologist who is a national authority on the use of radio-telemetry techniques on Perregrine Falcons. In March he retained Dr. Kirven as his assistant and also selected two field personnel.

The Falcons hatched four young but only three survived, all males. In all, four birds were radio-tagged and monitored, the adults and two of the young. There were many problems in development of data, particularly with the radio transmitters and the weather.

Monitoring began April 21 and ended July 12, but that does not represent continuous signals from any one bird. The female was trapped April 21, in a trap set for the male and resumed sitting on her nest for the next three weeks. On May 27 her antenna broke ending her monitoring. Only four days of data were obtained from the male before his transmitter failed and approximately seventeen from one of the young. The monitoring stage of the project ended July 12. Analysis of data developed during the project is currently underway and the conclusions and final report are due in october.

2. Data Base Acquisition: The contract with Sonoma Stcate University to design an Information Management system was completed in February, 1979. Their report provides the basis for bringing together all of the existing base data from previously prepared environmentally oriented reports about the KGRA.

The report provides a method for: acquiring the data; locating the data base at SSU Library; cataloging and classifying documents; a systems analysis; a cost proposal; and, a sample user survey. 
Three approaches are described in the report, differing in their costs and accessibility. A summary of the study and its costs is presented in Appendix A.

Results of this study were presented to the G.R.I.P.S. Commission Members during their March Meeting by a representative of the Sonoma State University Library. After the presentation, the Commission Members decided to establish an Advisory Committee with Commissioner Esposti participating to recommend which alternative should be selected and to develop methods of funding the system. The Committee has met once and follow-up activities have been suspended pending development of the financial capacity to carry out the. project.

3. Survey of Research in Geysers-Calistoga KGRA: In April, 1979, the G.R.I.P.S. Staff distributed 330 survey forms (see Appendix B) to various industries, academic institutions and government agencies involved in geothermal development. The distribution was derived primarily from the Geothermal Resource Council's Directory with emphasis on those organizations located in California.

A preliminary report was presented at the June G.R.I.P.S. Commission Meeting by the Staff Research Analyst. At that time, there was a $20 \%$ overall return rate. "The breakdown of forms sent, to those returned as follows: Academic 30\% returned; Government $44 \%$ returned; Industry, Utilities 0 returned; Industry, Steam Suppliers 25\% returned; Industry, Other (Manufacturers, Consultants, Engineering Firms, etc.) 15\% returned. Sixty-five reports were listed in the returns, but it was noted thirty-one were from one source.

Concern was expressed that the return responses from industry in general, was very poor. A follow-up letter (see Appendix C) was sent out on July 9 to those groups not previously heard from but who are reasonably expected to have a contribution to make.

The original returns included several projects of: significance of which G.R.I.P.S. was not aware but which will be obtained for eventual inclusion in the Information Management System.

The last of the follow-up: survey forms has been returned and the Final Report on the Survey will be included in the Contract Final Report. 
4. Comprehensive Air Monitoring Program: Late in 1978 the geothermal industry association, Geysers Geothermal Enyironmental Comittee (G.G.E.C) informed the Sonoma County Air Pollution Control District that the G.G.E.C. funding of the eight station Stanford Research Institute Air Monitoring network would be discontinued early in 1979.

After consultation with the Administrators of the two affected APCD's, representatives of the steam producers, utility companies and members of the CEC Staff, a three element "package" was developed to deal with the planned expiration date.

The package provided short term monitoring from March to June 1, 1979, interim monitoring to June 30, 1980, and development of a comprehensive plan for monitoring beyond June 30,1980 . The industry agreed to provide for the cost of the short term and interim monitoring. In March, the G.R.I.P.S. Commission approved the submission of a proposal for a Comprehensive Air Monitoring Program to C.E.C. for funding. (See Appendix $G$ for description of Proposal)

On May 9, 1979, the C.E.C. approved its contract with G.R.I.P.S. for the Comprehensive Air Monitoring Plan (C.A.M.P.) totaling $\$ 35,978$ and the contract cleared the State control agencies on. June 13 .

On June 8, 1979, the Project Coordinating Committee established in the proposed contract, met to discuss the role and scope of that Committee. At this time an Executive Committee was established. A copy of the Summary Notes of that Meeting are attached in Appendix $D$. John $T$. Walser, subsequently was selected to fill the position of C.A.M.P. coordinator beginning the first week of July.

On July 25, 1979 the Executive Committee approved the Work Plan for the program. On August 15, 1979, the Committee reviewed population dispersal and power plant/well site location maps. The next Comnittee Meeting is scheduled for September 14.

B. G.R.I.P.S. MEMBER ACTIVITIES

1. Sonoma County

a. Franz Valley Study: After several postponements, the Board of Supervisors adopted the land use and zoning plan on April 17, 1979. It basically aims to keep the largely undeveloped agricultural area unchanged. The study contains a statement concerning the location of geothermal power transmission lines which says: 
Except within the geothermal fields, any new transmission lines should parallel existing routes and be designed to minimize visual and community impacts.

b. Air Quality: On June 19, 1979, the Board of Supervisors passed a Resolution to execute a contract for $\$ 4,500$ with Form and Substance, Inc. to provide a technical review of Air Quality Analysis for proposed Geothermal Power Plant Unit 17.

\section{California Energy Commission}

a. Transmission Lines: After P. G. \& E. submitted the Notice of Intent for the Geysers 16 Power Plant, the C.E.C. directed that they incorporate a plan for transmitting power in excess of existing power line capacity out of the Geysers. P. G. \& E. submitted four alternative route proposals with the above ground route that crosses Franz and Alpine Valleys and continues through the development of Oakmont, to the Lakeville Sub-station shown as their preferred route.

After months of public hearings and investigations, the C.E.C. released their final report on August 16, 1979, recommending the preferred route of P. G. \&. E. through Sonoma County to the Lakeville Sub-station. The Energy Commission has now agreed to accept jurisdiction of an additional 54 miles of transmission line from Lakeville to the Sobrante Sub-station, and now must decide to extend the hearings on the N.O.I. or consider comments from the public during the A.F.C. process.

b. Geothermal Breakdown Problems: In June, the C.E.C. executed a contract with the Northern Sonoma County Air Pollution Control District for preparation of a report on Geothermal Breakdown Problems.

3. U.S. Department of Energy/Lawrence Livermore Laboratory

a. Rough Terrain Air Modeling Project: The following description of this project was included in a July, 1979. Newsletter.

"The DOE Atmospheric Studies in Complex Terrain (ASCOT) program officially began in October, 1978, after several planning meetings were held during the six months prior to October. This program is designed to develop the technology needed to perform air quality impact assessments for new energy sources in areas of complex terrain. To perform this function, the program integrates theoretical research, mathematical model development, field measurements and physical model experiments to improve fundamental knowledge and develop application techniques for pollutant transport and dispersion in terrain dominated flows. 
"The main program goal during the first three years is to develop an improved capability for assessing the air quality impact of power generation within typical valley drainage flow. The specific site chosen for the drainage wind study is the Anderson Creek Valley in the Geysers Known Geothermal Resource Area (KGRA) near Clear Lake, California. Although the study is applied to a location of geothermal energy development, results and techniques developed during the study can be applied to other regions where drainage winds are important in assessing the air quality impact from power generation sources.

"The ASCOT program is largely a multi-DOE or DOE sponsored laboratory program with the Los, Alamos Scientific Laboratory (LASL), Lawrence Livermore Laboratory (LLL), NOAA/Atmospheric Turbulence and Diffusion Laboratory (ATDL), and Pacific Northwest Laboratory (PNL) the major participants. The National Laboratory (BNO), Savannah River Laboratory (SRL), and the University of Utah are at present participating to a lesser degree.

"After the field program measurements, and the numerical modeling program planning were completed, a Planning Meeting was held in Denver, Colorado on June 20,21 to discuss the contributing roles of the various national labs participating in the scheduled field program of meteorological measurements. The field program measurements took place at the Geysers KGRA July 15-28."

b. Socio-Economic Study Project: This project was first presented in detail to G.R.I.P.S. at the February 23, 1979, Technical Advisory Committee Meeting during a program devoted entirely to the LLL projects. Because there was insufficient time at that meeting to discuss the project in depth, a follow-up meeting was scheduled to allow input from the local level while the project was still in its formative stages. The emphasis was for the lab to use their resources in ways that can provide tools for the local planners which could be integrated with other information to aid them in the decision making process while meeting the needs of the LLL/DOE Agreement.

The goal of the socio-economic research program is to facilitate geothermal energy development in the GeysersCalistoga KGRA by assisting DOE and local agencies in project design and development management that respects environmental constraints. Socio-economic environmental constraints include those imposed by federal and state statute, local ordinance, policy, regulation or custom.

A nember of the G.R.I.P.S. Staff has accompanied their research team to Lake, Mendocino and Sonoma Counties to meet with various County Personnel and gather local available data. The LLL-research team also visited Napa County to gather information. The socio-economic 
group has hired a former member of the Lake County Planning Staff.

They initiated preparation of a series of approximately 30 geocoded digitized maps which delineate Lake County's land and infrastructure capabilities.

During the month of July, sub-contractor Dr. Jerry Johnson, a social-psychologist from the University of Hawaii, spent a week in Lake County doing research on the sociological impacts of geothermal development in that county.

G.R.I.P.S. is actively pursuing communications and periodic progress checks with this group.

c. Long Term Ecosystems Assessment of Geothermal Development: This project is divided into two sections: 1) Terrestrial studies; and 2) Aquatic Studies.

1) Terrestrial Studies: Field plots have been established both for existing power plants and proposed power plants with P. G. \& E.'s technical cooperation. They are monitoring for trace element baseline information in the soil, plant and small mammal life.

The cooling tower drift deposition goes beyond what P. G. \& E. has already done. An active atmospheric monitoring system involving an intensive study of drift monitoring around P. G. \& E.'s Unit 12 was activated from June 25 to July 2, 1979. Three groups participated: LLL, Pacific Northwest Labs; and Environmental Systems Corporation, Knoxville.

Plant life in the field will be examined as part of the short term drift characterization from trace element concentrations. Experiments are also being conducted in the labs growth chamber.

2) Acquatic Studies: Acquatic studies will attempt to assess the long-term responses to: sedimentation and natural seeps, and validate LLL's methodology by experimental watershed studies. Their methods will include model calculations of geochemistry techniques, water chemistry of the natural seeps and experimental studies in the Upper Putah Creek Tributaries.

The last week of July there was a coordinated study of fish collection in Putah Creek by four groups: Joe Shinn, LLL; Vince Resh, U. C. Berkeley, College of Natural Resources; Peter Moyle, U.C. Davis, Division of Wildife and Fisheries; Bob Ireland, LLL. 
The results of this survey it is hoped will serve as a prototype scheme for assessing aquatic accumulation in an area of continuing development which could be applied to watersheds of new developments.

d. Environmental Control Technology: Evaluation of Abatement Systems LLL is involved in an ongoing evaluation of on-line hydrogen sulfide abatement systems which includes research into possible improvements of these systems. This project is not limited to the Geysers-Calistoga K.G.R.A. but it is hoped some of their results will be applicable to the area. This project has been partially completed and there is a report in preparation.

e. Health Assessment Program: LLL is anticipating a contract with the California Department of Health Service for research into health impacts resulting from geothermal development.

It is possible that G.R.I.P.S. will participate in a coordinating capacity between the locals and LLL/DHS.

f. Overview: Volume four, Environmental Geology, of the LLL/DOE Environmental Overview project has been published and is being distributed to interested parties. A draft of the SocioEconomic report has been prepared and distributed for review.

C. OTHER GOVERNMENTAL AGENCIES

1. California Department of Conservation:

The Division of Mines and Geology will be doing an assessment of the quantity and temperature of geothermal water found near the town of Calistoga. If proven adequate, Calistoga will be eligible for a grant to build a desalinization plant, which would provide a needed fresh water resource to the area.

2. U.S. Bureau of Land Management:

a. Endangered Plant Species Baseline Data: BLM has developed plans to photograph threatened and endangered plant species on BLM property to establish baseline data for determination of geothermal development impact on such species.

Due to a need for field work on regular projects, no contract will be issued this fiscal year. A botanist will be assigned later this year who will work with the Native Plants Society to analyze the available data. It will then be determined what is needed when field work begins in the spring of 1980 . 
b. Water Quality Analysis: The BLM has contracted with the U.S. Geological Survey to do water quality analysis in areas of Sulphur Creek which cross through. BLM Lands. The project started in October, 1978 and ran until January, 1979, when a lack of funds caused a six week lapse in some of the data collection systems. In March the full monitoring resumed and is ongoing.

c. Cultural Resources Overview: BLM Staff has developed a program to carry out a Cultural Resources Overview Study for all BLM lands subject to geothermal leases. A Request for Proposals has been distributed and a contract award is pending for 3 Class 3 Archeological Inventory as the first part of the program. BLM is attempting to coordinate this program with the California Energy Commission, the State Lands Commission and G.R.I.P.S. with a goal of developing a Cultural Resources Overview which covers the whole K.G.R.A. To date only BLM has developed the finding for its share of the program. Determination on funding for the other agencies should be forthcoming during the coming year.

\section{INFORMATION EXCHANGE}

The Bi-Monthly G.R.I.P.S. Activities Reports for January and February, March and April, and May and June provide extensive detail on information exchange activities. The following items are the more significant activities described in those reports, copies of which will be included as appendices in the Contract Final Report.

2/23 The entire agenda of the February 23rd G.R.I.P.S. Technical Advisory Comittee Meeting was devoted to a presentation by Lawrence Livermore. Laboratory and Lawrence Berkeley Laboratory Staff Representatives regarding the projects discussed in Section I above.

3/16 G.R.I.P.S. Staff held a meeting to discuss the LLL/LBL Socio-Economic Study with representatives from Sonoma and Lake Counties, steam suppliers, California Energy Commission, Bureau of Land Management, P. G. \& E'., and Lawrence Livermore Laboratory/Lawrence Berkeley Laboratory. The Meeting allowed each representative an opportunity to express what areas they would like to see addressed in this study. The labs' representatives explained what products the study would provide which could be used as planning tools by the counties and various other organizations involved in geothermal deyelopment. 
4/11 The Executive Director made a presentation on G.R.I.P.S. activities to the GRB. TAC Meeting in Sacramento.

4/24 The Executive Director made a presentation to the Boards of Supervisors for Lake, Mendocino, and Sonoma Counties about the status of the BLM mineral lease fund allocations as well as the status of G.R.I.P.S.

4/27. The Executive Director attended an information seminar of the Geothermal Task Force, Sonoma County Alliance, an organization whose membership includes representatives of the geothermal industry, labor, and the Farm Bureau.

5/8 The Executive Director; Dave Hill, C.E.C.; and Steve Zalusky, Lake County Air Pollution Control District; met with Geysers Geothermal Environmental Committee concerning the Comprehensive Air Monitoring Contract being considered by C.E.C. The meeting was an informational exchange allowing industry to make inquiries as to the scope, purpose, and goals of the proposal.

5/18 G.R.I.P.S. Commission Chairman, Dowell Martz and the Executive Director met in Angwin to discuss a proposal on geothermal reservoir identification with State Division of Mines and Geology's Research Staff.

5/21 The Executive Director and Research Analyst met with Benjamin Kor, Supervising Engineer for the Regional Water Quality Control Board, North Coast Region, at their Santa Rosa Offices to discuss geothermal related water quality issues in the Geysers Area. Their jurisdiction does not cover the entire KGRA. The remainder of the KGRA is the responsibility of the Sacramento office. The Executive Director met with the Staff in that office in July.

6/1 The Executive Director attended the C.E.C. 1979-1980 work program review held in Davis.

6/11 The Executive Director, Energy Commission Suzanne Reed, Kathryn Tobias - OPR, and Nancy Deller C.E.C., met with Assemblyman Bosco to discuss the GRB TAC Legislative Package.

From March to June the Executive Director met with the GRB-TAC Sub-Committee in Sacramento on a regular basis to work on a legislative proposal for distribution of BLM Mineral Lease Revenue Funds. 
6/27 The Executive Director participated in a panel discussion at Sonoma State University's summer course funded by D.O.E. entitled "Geothermal Energy and the Environment". This course is open to high school and junior college science teachers in the fields of biology, chemistry, physics, and earth science.

\section{FUNDING PROPOSALS}

The Bi-Manthly Status Reports include detailed discussions of each month's activity under this heading. The following are the more significant actions undertaken:

- At its March 15th Meeting the G.R.I.P.S. Commission authorized submission of a proposal to the U.S. Department of Energy for a contract to cover the cost of the administration of the G.R.I.P.S. Commission from September 1, 1979, to August 31, 1980, and for the project entitled "County Geothermal Policy Development". This proposal is still under review and in the final stages of negotiation between the G.R.I.P.S. Commission Staff and the U.S. Department of Energy Regional Office. A summary description of the G.R.I.P.S. Administration Proposal is attached as Appendix $E$ and a summary description of the County Geothermal Policy Development proposal is attached as Appendix F. The full proposals will be included as appendices to the Contract Final Report.

- On March 15th, the G.R.I.P.S. Commission established as its top priority for allocation of California Energy Commission Funds, the proposed Comprehensive Air Monitoring Program. The proposal is described in the covering letter for submission to James Walker, C.E.C. (see Appendix G).. The California Energy Commission approved a contract for that program on May 9 th and the G.R.I.P.S. Office received notification of final approval of the Contract by State Control Agencies on June 13, 1979.

IV. ADMINISTRATION OF G.R.I.P.S.

- At its February 11th Meeting, the Commission re-elected Napa County Supervisor, Dowell Martz, as Chairman of the Commission for the 1979 calendar year and elected Mendocino County Supervisor, James Eddie, as Vice-Chairman.

- During Phase II, the Commission held regular Commission Meetings on February 8 th, March 15th, May 10th, June 14th, and July $12 \mathrm{th}$.

- At its March 15th Meeting, the Commission established recommended priorities for the expenditure of California Energy Commission Funds in the Geysers Area. 
- The July 12, 1979 Commission Meeting included a Work Session with representatives of the geothermal industry as the first of several evaluation Work Sessions. The next such Work Session will be on September: 7 th with representatives of the County Planning Departments and other local State and Federal Agency Staffs who have an interest in G.R.I.P.S. program activities.

\section{SUMMARY}

The following list includes summarized comments on those activities of the Commission and its Staff during the Phase. II which have been directed toward accomplishing the responsibilities assigned in the Joint Powers Agreement and the work activities agreed upon in the contract with the California Energy Commission.

- The design for an Information Management System has been completed and an effort is underway to obtain funding to establish this system (see appendix A).

- Close working relationships have been developed with local, state and federal organizations involved in geothermal development, particularly: Northern Sonoma County Air Pollution Control District; Lake County Air Pollution Control District; the following State of California organizations - Geothermal Resource Board Technical Advisory Committee, California Energy Commission, Division of $0 i 1$ and Gas, Department of Water Resources, Department of Conservation, State Lands Commission, Office of Planning and Research, and Air Resources Board; and the following Federal Agencies - Department of Energy, Bureau of Land Management, U.S. Geological Survey, Environmental Protection Agency.

- The Staff has completed a survey of geothermal research activities in the Geysers-Calistoga Known Geothermal Resource Area.

- The first "area-wide" project has been initiated - the Comprehensive Air Monitoring Program. This project includes participation by the two primary Air Pollution Control Districts, State Energy Commission, State Air Resources Board, Division of $0 i 1$ and Gas, California Department of Health Services, Steam Suppliers, Steam Utilities, U. S. Bureau of Land Management, U. S. Department of Energy, U. S. Environmental Protection Agency, and the G.R.I.P.S. Commission Staff.

- Refunding for the operation of the basic G.R.I.P.S. Staff has been obtained for the period September 1, 1979 - September 1, 1980.

- Funding has been obtained for the County Geothermal Policy Development Program which will provide member counties with base information and research required for the establishment of county policies on geothermal development including geothermal elements, and for coordinated policies between the counties on issues which cross county lines. 
- The Commission has involved geothermal industry representatives in its activities in both Commission and Technical Advisory Committee Meetings and on Commission Committees such as the. Information Management Committee and the Comprehensive Air Monitoring Project Coordinating Committee.

- The distribution list for agendas, reports, and other materials related to G.R.I.P.S. activities now exceeds 70 .

VI. AREAS FOR FUTURE CONSIDERATION

M.E.A./E.I.R. Role: The G.R.I.P.S. Plan suggested the concept that G.R.I.P.S. will "develop the capacity to produce a Master Environmental Assessment for the Geysers-Calistoga KGRA. G.R.I.P.S. will also deliver the capability to produce EIR's and EIS's needed for permitting decisions on geothermal development in the counties". This responsibility can not be undertaken until the Information Management Base has been acquired and made usable through a proper cataloging system. Efforts during the past year to obtain funding to establish this system have not been successful. If such a system is to be established soon enough to be of use in impending power plant and well field development, funding for the program must be obtained before the end of this year.

Geothermal Industry Participation: Some representatives of the industry take the position that G.R.I.P.S. role should be limited solely to the acquisition of the Information Base. They fear that G.R.I.P.S. will become another layer of red tape delaying development of geothermal resources. This perception is in conflict with the assignment given by the California Energy Comission in the current contract and with the Work Program outlined for the Federal Cooperative Agreement which will provide funding for the second year of G.R.I.P.S. operation. In both cases, G.R.I.P.S. is assigned responsibilities which should tend to expedite geothermal development rather than hinder it as some of the industry representatives fear.

An important resource for the projected G.R.I.P.S. Information Base will be research and basic data developed by industry sources. This then gives a high priority to actions by G.R.I.P.S. which are directed toward developing full credibility in the eyes of those members of the geothermal industries who feel that G.R.I.P.S: present course is potentially a threat to industry interests.

Public Participation: The activities of the G.R.I.P.S. Commission during the last year have not generated significant public participation in Commission activities. As the Commission moves further into the development of an Information Base for County Geothermal Policy, there will be more extensive efforts directed toward generating public participation. If G.R.I.P.S. is able to initiate development of a Master Environmental Assessment such a process will also mandate major efforts to sustain public participation. 
Direct Heat/Non-Electric: G.R.I.P.S. role in the development of direct heat utilization of the geothermal resource needs to be considered. As an example, at the request of the Mendocino County alternate G.R.I.P.S. Commissioner, Norman DeVall, the Executive Director has set up an exploratory meeting to consider the use of geothermal resources in meeting a need for development of a fish freezer facility to serve the North Coast area.

The Commission should develop policy and guidelines regarding the level of Commission and Staff involvement in this area. As the only local Staff devoted solely to geothermal development in the four counties, G.R.I.P.S. is in a unique position to be of service to the counties. Such service could include: provision of basic information; acting as catalyst on demonstration project development; instigation of research on specific problems; stimulator of activity by outside agencies in this area; etc.

RFV : PB : seb

$8-21-79$ 
DESIGN FOR INFORMATION

MANAGEMENT SYSTEM

\section{SUMMARY}

This report provides the design of an Information Management System to assembly, classify, and catalog existing documentation on the development of the Geysers/Calistoga Known Geotherma1 Resources Area (KGRA). The study, carried out by the Ruben Salazar Library at Sonoma State University, consisted of several components :
1) User need requirements,
2) design of the system,
3) survey of information management systems, and
4) systems analysis and cost proposal.

User input concerning information requirements and system characteristics were obtained from interviews (personal and telephone) and a questionnaire. The sample user popilation expressed a need for the identification and access to relevant information concerning local geothermal development. Furthermore, it was a consensus of opinion that the creation of an information center as a depository for relevant documentation would be useful in meetings information needs. Sonoma State University was considered an ideal organization to meet this objective.

The Information Management System was designed with several criteria in mind.
1) Low maintenance and ease of updating,
2) extensive subject access, including geographical coding,
3) widespread dissemination of the result,
4) and use as a research collection rather than just a collection of documents.

Thus, the result would be a system with considerable utility as a resource, yet low in maintenance after project termination. To meet these objective the production of a book catalog utilizing automatic data processing (ADP) and a data base management system (DBMS) approach is proposed.

A book catalog is recommended since once completed, no maintenance would be required; the product could be disseminated in hard copy and microfiche, and indexing would be extensive enough to meet the needs of a complex and disparate user population. The catalog would also contain full bibliographic descriptions for all records as well as abstracts for highly significant documents. Updating would be a 
relatively low effort task.

Three levels of Information Management Systems support were determined as alternatives for the project. The first level would support the production of the book catalog. The in-house computing capability at Sonoma State University would sufficiently meet the ADP requirements at this level. The second level would also produce the book catalog but, in addition, would provide an on-line, remotely accessible interactive search capability. The advantages of the second level would be to extend the range indices. By using Boolean operators concepts rather than words could be used as a search profile. Thus, specialized bibliographies could be generated tailored to the specific needs of the end user. Access would also be enhanced since the system could be tied into with any remote terminal and an easily obtainable account number. The ideal support system for the second level would be Stanford University's SPIRES system.

The cost for the first level system would be $\$ 86,454$. The second level system would be $\$ 106,454$. These would be one year operating costs. The time frame would be approximately six months to produce a catalog containing the retrospective collection. The remaining six months would be for supplements and providing information services such as reference and referral. A third alternative was requested after the body of the report was completed. In this anternative, a card catalog could be prepared, the documents assembled in a special collection, and reference services would result in a $\$ 20,000$ price reduction from plan one. This value is derived by eliminating the computer center cost and reducing by 50 percent student assistants and the consultant. Further reductions would of course be possible by eliminating other components of the system. For instance, reduce reference services, minimize retrieval of documents, less subject access, etc.

A minimal one-year operation will require at least the full-time information specialist, half-time clerical assistant, student assistants, and the supplies and services. This amounts to approximately $\$ 50,000$. For this price, the documentation would be identified, collected, the card catalog prepared and the system maintained over the one-year operation.

The most significant limitation with this plan would be the loss of the concept of information utility that the proposed plan one provides, i.e., having the collection in book catalog format, with abstracts and subject access. In the alternatives, the system becomes merely a depository. At the end of the project, the result will be a static collection with the problem of maintaining the integrity of the catalog. Distribution of the catalog would only be possible by photocopying the cards. 


\section{RESEARCH SURVEY OE GEYSERS-CAIISTOGA KGRA}

G.R.I.P.S. Commission, 2628 Mendocino dvenue, Santa Rosa, California 95401

The purpose of this survey is to develop a comprehensive report of all research, either on-going or proposed, in the Geysers-Calistoga known Geothermal Resource trea (KGRA). If you have any questions regarding completion of this form, please contact Paula Blaydes at (707) 527-2025. Thank you for your cooperation.

1. No research project proposed or in progress.

2. Are you interested in obtaining the results of this survey?

3. What is the tigle of your project?

4. Please idencify the organization responsible for initiating your research project.

Name:

Address :

Concact Person:

Phone Number:

5. If the research is being conducted by others, please list who they are.

6. Briefly describe the project.

7. Indicate the date the project started and estimated completion time. (If it is not yet in progress, indicate when you expect it to be. 
3. If the project is in progress, please give a brief description of its current status.

9. Is there an advisory group working on the project, and, if so, please identify Ehen.

10. Are funds already allocated for the project?

11. If so, please identify your source of funding.

12. Will this project result in a publication?

If so, when do you expect its completion?

Will it be available to G.R.I.P.S.?

ivill it be available for broader distribution?,

13. Please Indicate the geographical boundaries of your project area. 


\section{G.R.I.P.S. COMMISSION}

2628 MENDOCINO AVENUE, SANTA ROSA, CALIFORNIA 95401 (707) 527-2025

July 9,1979

Dear

One of the purposes of the G.R.I.P.S. Commission is to compile an information base to benefit all interested parties.

In April, G.R.I.P.S. mailed a brief survey form to your organization requesting a few minutes of your time to complete it. As our preliminary results are tabulated, it has come to our attention that we have not yet received a survey reply from your organization. Because we wish our survey to be as complete as possible, another survey form is enclosed for your convenience. We would appreciate your cooperation in filling it out or referring it to someone else in your organization who may be more appropriate. Any research project your group may have either completed, continuing, or proposed would be of interest to G.R.I.P.S.

If you do not have any research projects,.. simply put a check mark in Question 非 1 , but please identify yourself in Question 非 Please return to our above listed address by Monday, July 30 .

Thank you for your cooperation.

Sincerely,

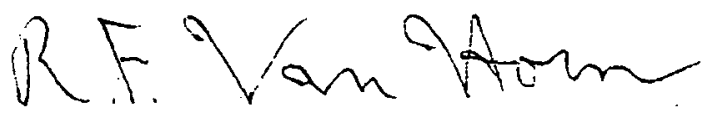

ROBERT F. VAN HORN

Executive Director

RFV : seb

Geothermal Research Information and Planning Services/A California Joint Powers Agency

Lake County

Mendocino County

Napa County

Sonoma County 


\title{
G.R.I.P.S COMMISSION
}

2628 MENDOCINO AVENUE, SANTA ROSA. CALIFORNIA $95401 \quad(707) 527-2025$

\author{
SUMMARY MEETING NOTES \\ COMPREHENSIVE AIR MONITORING PROGRAM \\ PROJECT COORDINATING COMMITTEE
}

June 8, 1979

Project Coordinating Comnittee Members:

California Air Resources Board

Bureau of Land Management

California Energy Commission

California Department of Health Services

California Division of $O i l$ and Gas

Environmental Protection Agency

Lake County Air Pollution Control District

Northern Sonoma County Air Pollution Control District

Utilities (P.G.\&E.)

Steam Suppliers (Union Oil)

U. S. Department of Energy

Staff Resource Members:

G.R.I.P.S. Executive Director

G.R.I.P.S. Research Analyst

California Energy Commission, Contract Manager
Bob Maxwe 11

Eritz Lloyd

Jeff Anderson

Jeff Hahn for Larry Perry

Ken Stelling for Linda Ferguson

Rod. Cummins (Absent)

Steve Zalusky

Mike Tomalsoff

J. T. Holcombe

M. Von Der Porten for Warren Smitr

Cal Jackson (Absent)

Robert Van Horn

Paula Blaydes

Dave Hill

\section{1) Project Coordinator:}

The role of the PCC was discussed in selecting the Project Coordinator.

The Group decided to have Bob Maxwell - ARB, Warren Smith - Union Dil,

Mike Tomalsoff - Northern Sonoma County Air Pollution Control District, and

Dave Hill, Contract Manager - C.E.C. serve on the application screening and

interview committee with the G.R.I.P.S. Executive Director.

\section{2) Program Scope:}

Since the Coordinator may not already be familiar with the problems involved, it was determined the PCC Committee should give as much input as possible to help facilitate development of the Project Coordinator's work program. After the Coordinator is hired, a time limit to develop the work program will be established. It was generally acceptęd by the group that the work program would provide plans for a ten year monitoring program.

\section{3) Committee Organization:}

Due to the difficulty in coordinating this number of people for regular meetings,

it was resolved that there would be an Executive Committee, consisting of

Geolhermal Resource Impact Projection Study ; A California Joint Powers igency 
Sumary Meeting Notes

G.R.I.P.S. Air Monitoring Program Project Coordinating Comittee

June 8,1979

Page 2

rotating members from each of the major groups represented. To assure greater participation in future meetings, each member would.assume the responsibility of finding an alternate to come in their place if they are unable to attend a meeting. The Executive Committee Membership for the next meeting is comprised of: Lloyd Fritz - BLM, representing the Federal interests; Ted Holcombe - P. G. \& E., representing the Utilities; and Warren Smith - Union Oil, representing the Steam Suppliers; Jeff Anderson, representing the State; Steve Zalusky-I.C. $A P C D$, representing local interests.

4) Program Boundaries:

Before the meeting adjourned, the P.C.C. agreed on the preliminary program boundary lines. These boundaries extend beyond the KGRA boundaries to include urban areas where the impact of geothermal may already be affecting the air quality or potential impact could occur if development continues to grow as expected. In addition to the basic Lake and Sonoma County study areas, there are three contiguous segments in the Counties of Mendocino, Napa and Colusa for which basic information may be developed dependent upon need.

$\mathrm{PB}: \mathrm{seb}$

6-13-79

Attachment 
PROPOSAL SIMMARY

G.R.I.P.S. COMMISSION

1979-80 G.R.I.P.S. ADMINISTRATION

\section{PROGRAM}

This grant will provide for the continuation of the central G.R.I.P.S. Administration Staff which serves the 4 County Joint Powers Commission whose membership includes non-voting representatives of the Department of Energy and the California Energy Commission. Activities carried out under this grant will include: development and coordination of multi participant projects for reducing barriers to geothermal development; identification of institutional and environmental issues which may impede geothermal development; provision of a geothermal information exchange; development of priorities for research activities; etc.

\section{DELIVERABLES}

- Bi-Monthly progress reports

- Research and Project reports

- Annual report covering; geothermal development; county geothermal policy development; evaluation of intergovernmental and producer cooperation; research need priorities

\section{BUDGET}

\begin{tabular}{lr} 
Salaries and Employee Benefits & $\$ 76,769$ \\
Services and Supplies & 15,428 \\
Travel & 5,000 \\
\hline & $\$ 97,197$
\end{tabular}




\section{PROPOSAL SUMMARY \\ G.R.I.P.S. COMMISSION \\ 1979-80 COUNTY GEOTHERMAL POLICY DEVELOPMENT}

\section{$\underline{\text { PROGRAM }}$}

This grant will provide the basis for the development of comprehensive policy at the county and K.G.R.A. wide level for both electric and non electric geothermal development in the Geysers-Calistoga K.G.R.A. It will also provide funding for the preparation of comprehensive policy reports on three K.G.R.A. wide policy issues.

\section{DELIVERABLES}

- Identified Policy Alternatives

- Work Program and R.F.P.s for policy actions

- R.F.P.s For policy reports on K.G.R.A. wide policy on Wildiffe Habitat, Sensitive Open Space and Stream Protection

- Comprehensive Policy Reports on Wildife Habitat, Sensitive Open Space and Stream Protection

Salaries and Employee Benefits

Trave 1

Overhead

Consultant Fees
S 33,181

1,700

10,465

55,000

$\$ 100,346$ 


\section{G.R.I.P.S COMMISSION}

2628 MENDOCINO AVENUE, SANTA ROSA. CALIFORNIA 95401 (707) 527-2025

March 13, 1979.

James Walker, Executive Director

California Energy Commission

1111 Howe Avenue

Sacramento, California 95825

Attention: Nancy Deller

Dear Mr. Walker:

At the February 8, 1979, G.R.I.P.S. Commission meeting Nancy Deller presented a copy of your February 8 letter which stated that the top priority study need for The Califorria Energy Commission is Air Quality Monitoring. Enclosed is a proposal to develop a comprehensive plan for Air Monitoring in the Geysers-Calistoga K.G.R.A. This has been developed for submission because Air Monitoring is also one of the top priority projects of the G.R.I.P.S. Commission.

I received telephone approval from the members of the Commission to submit this proposal and will have it on the March 15, G.R.I.P.S. Commission meeting agenda for formal approval.

The proposal has been developed after consultation with the administrators of the two affected A.P.C.D.s, representatives of the steam producers and the utility companies and members of the C.E.C. staff. It is part of a 3 element "package" which will provide short term monitoring from March to June 1, 1979, interim monitoring from June 1, 1979, to June 30,1980, and the comprehensive plan for monitoring beyond June 30,1980 . The industry will provide for the cost of the short term and the interim monitoring and will anticipate that the comprehensive planning effort will develop a program to define longer term financial requirements.

On March 8, I met with representatives of the C.E.C.. and A.R.B. and the two A.P.C.D. administrators to discuss the proposed Comprehensive Planning program and the outline of the proposed interim program. At that time no major points of disagreement were developed: regarding the proposal to carry out the comprehensive planning program and it was agreed that the interim proposal would be submitted to the $C, E, C$. and A.R.B. staffs for review and comment. We feel it necessary to receive 
the resules of those reviews prior to forwarding the interim monitoring proposal to the industry group (Geysers Geothermal Environmental Committee) for their approval and funding.

If you have any questions about the Air Monitoring Long Range proposed Comprehensive planning program, please give me a call. We will look forward to an early iavorable response to our proposal.

Sincerely,<smiles>[CH-]C=C</smiles>

Robert F. Van Horn

Executive Director

G.R.I.P.S. Commission

RVH: jal 